\title{
TTR
}

Traduction, terminologie, re?daction

\section{Deviation and Translation}

\section{Mladen Jovanović}

Volume 4, numéro 1, 1st semester 1991

Languages and Cultures in Translation Theories

URI : https://id.erudit.org/iderudit/037083ar

DOI : https://doi.org/10.7202/037083ar

Aller au sommaire du numéro

Éditeur(s)

Association canadienne de traductologie

ISSN

0835-8443 (imprimé)

1708-2188 (numérique)

Découvrir la revue

Citer cet article

Jovanović, M. (1991). Deviation and Translation. TTR, 4(1), 83-98.

https://doi.org/10.7202/037083ar

Tous droits réservés @ TTR: traduction, terminologie, rédaction — Les auteurs, d'utilisation que vous pouvez consulter en ligne.

https://apropos.erudit.org/fr/usagers/politique-dutilisation/ 


\title{
Deviation and Translation
}

\author{
Mladen Jovanović
}

\section{Intralanguage communication}

According to one definition, language is a system of systems (of codes, of rules). There is, for instance, a system of words and a system of rules governing the arrangements of those words into sentences. In its turn, language (verbal communication) is embedded in, and depends upon, other, nonverbal systems of communication. Ordinary, intralanguage communication (communication among the speakers of the same language) is made possible by the fact that the members of a social and language community know, intuitively, the above-mentioned systems and the extralinguistic reality (the culture) they live in - the reality which is structured by, and mirrored in, the language they speak and which, structured as it is, is the subject matter of language communication.

It should be noted at this point that - because of the nature of language and the structure of the humian mind - no language communication is ever perfect and that reality is the ultimate judge on what is right in language and language communication. It is this reality that shapes the rules of language communication.

\section{Interlanguage communication}

Communication among the speakers of different languages (interlanguage communication) is a mediated communication, a communication effected by means of translation (or translators, to be more precise). The task of the translator is to make it possible for a 
speaker of one language to receive a message sent (to him) by a speaker of another language.

Although I do believe in the monistic nature of language communication, in the unity of form and content, the phenomenon of translation has to be looked upon from the dualistic point of view since the message (the content, the meaning) is first encoded (given form) in one language, and then decoded (received, understood), and only then transcoded (given another form) into another language. It is here, in this process of transcoding, that the crux of translation is to be found because translation skill (translation art, craft), in my opinion, is nothing but the skill of matching the patterns of two different languages against the background of one and the same objective extralinguistic reality structured differently by the two given languages. Needless to say, the pattem-matching skill is not solely and exclusively a translation skill - it is an element of general intelligence.

\section{Norms}

As already stated, intralanguage communication is made possible by the fact that the speakers of a language know the rules of the language they speak. However, since one of the basic characteristics of language is change, those rules also change, in space and time, endangering communication (a tendency toward entropy). For this reason, those rules may sometimes be explicitly stated and prescribed, in a rule book (the grammar of the language) for the purpose of enforcing them (one of the forces working against entropy). Sometimes, for social, economic, political and other reasons, those rules are maintained, although not officially prescribed. $\mathrm{Be}$ it as it may, one way or another, those rules tend to become a norm, a standard to be respected, and emulated, and maintained - and deviated from.

\section{Deviations}

Once, breaking the rules of language, or deviating from the norm, from the standard, was not really understood and, probably, for this very reason, was looked down upon and proscribed - except for the deviations in poetry, known as "poetic licence", which were accepted. Today, we know that there are at least two large groups of deviations, both seen as natural aspects of language and throwing more light upon 
the workings of language. The first includes unintentional deviations. The second intentional deviations. These two groups can, themselves, be subdivided into smaller groups. It is one such subgroup that I am interested in here: intentional systematic and systemic deviations.

\section{Goals}

In this paper I intend to discuss some problems of translating literary texts characterized by what has been called "poetic licence", "deviation from the norm", "breaking the rules of language" or, sometimes, "illiteracy", "the lack of knowledge of the language", etc. I advocate a conscious, planned approach to the problem of translating deviations, an approach based on translation theory, where theory is defined as: (1) the knowledge of the way language mechanism, particularly that of the written language, works, (2) the knowledge of the source and the target languages, (3) the (what little) knowledge (there is) of the way native speakers of the two languages read (understand, interpret) written texts of their mother tongues ${ }^{1}$, (4) the knowledge of the two

1. In 1968, at Teachers College, Columbia University in New York, I conducted an experiment in short-term memory (Jovanovic, 1977). The experiment centered on the comparison of the effects on shortterm memory of the repetition of a word in a random word list and that of the inclusion of an associate in the same list. Some of the results of that experiment were curious. Namely, the subjects reported to have read (memorized and then written down) words that were not on the lists of words they had read. Those new words were of four types: (1) words of the smoke+fog=smog type, (2) words, associates of words from the lists, but not the target words, (3) words with the collocation relationships with those on the lists, and (4) new words which it was impossible to explain.

Although the experiment was dealing with isolated words, not sentences, the results showed that even at that level the subjects were trying to connect those words into larger units, to come up with some overall meaning. Since then, I have come across other psychological (the Rohrschach test) and psycholinguistic data proving, to my satisfaction, the truth of the words of Duke in Shakespeare's As You Like It who "finds words in trees, books in the running brooks" - in other words, the ability of the human mind to give meaning to, to force meaning upon, everything it perceives. I should add here that without these insights into the workings of the short-term memory I would not have been able to analyze the texts presented in this paper. 
cultures, i.e., the way of life of the social and linguistic communities speaking the two languages, and (5) the knowledge of the way the text in the source language can and should be substituted with the text of the target language (the pattern-matching skill).

\section{Assumptions}

This paper is based on a number of assumptions. First, in good writers, deviations from the norm are, themselves, systematic, i.e., they follow certain rules of their own, and systemic, originate in the language system they deviate from. Second, a translator should be capable of conscious, linguistic analysis of the text he is translating. Third, there is no translation without understanding, and fourth, deviations change, or add to, or modify, the meaning of the texts they are parts of.

\section{Understanding deviations}

Understanding deviations is like understanding figurative meaning first you have to know the literal meaning and only then can you hope to understand the figurative (metaphorical) one. What this means is that you have first to understand the rule, and only then the meaning of breaking it.

\section{Texts in the source language}

The examples presented here are based on the study and translation into Serbo-Croatian (SC) of the texts of James Joyce, e e cummings and William Faulkner, authors known for their language which is a challenge to readers, but also to translation theory in general and individual translators in particular. As already stated, I believe that deviations, if they are to mean anything, have to be consistent, systematic and systemic. If not, they cannot be used for communication - they will remain mere deviations without much meaning. Our authors, as far as their texts cited in this paper are concerned, are, in my opinion, O.K. in this respect. 


\section{Procedure}

Sometimes, in order to arrive at an understanding of a text, of a work or art which is to be translated, an understanding which is conditio sine qua non of a good and successful translation, one reading might be enough. More often, though, and in the case of texts with deviations in them almost always, one reading is not enough. It is necessary to apply one or more of the following steps.

Consult the author. Easier said than done. Most authors do not want to talk about their works. Some do, and they may be consulted. Sometimes one might want to consult the author's manuscript(s).

Research of critical literature. If consulting the author is not feasible, the first thing to do is to research the critical literature on the author and his work. One should not expect to find an objective, scientific - i.e., linguistic - description of the author's language (one almost never finds it in literary criticism), much less of his deviations, but educated guesses, opinions, maybe an insight or two. One should not be surprised to find all this, but also attempts to "correct the deviations" in the author's language, to make it "fit the norm".

Analysis of source texts. The next, probably the most important step, is the analysis of the text where deviations occur. Sometimes, a straightforward linguistic analysis is enough. Sometimes, however, something more is needed - semantic, psycholinguistic, sociolinguistic, etc., analyses - depending on the deviation in question.

Contrastive analysis of two languages. The contrastive analysis of the two languages is the next, equally important step. Needless to say, it is limited to those aspects, categories and levels of the source language which the author of the text has made use of (and the corresponding aspects, categories and levels of the target language).

Contrastive analysis of two cultures. The contrastive analysis of the two cultures - as reflected in the two languages - is usually carried out together with the analysis of the two languages. It is, also, limited to those aspects of the two cultures which have some bearing upon the text and the problems related to its translation. 
Translation. All these analyses should make it possible for a translator to match the linguistic patterns of one language with those of the other in an attempt to preserve the meaning of the original which is the actual translation.

\section{Presentation}

Although I would like to limit myself to the discussion of only one type of deviation, the nature of language, the interdependence of its various levels makes it always necessary to take into account one or more other language levels.

In my presentation, I shall use examples from English (as the source language) and SC (as the target language). Also, most of the time, I shall limit myself to presenting the results of my analyses, and not those analyses themselves. Interested readers are referred to literature where those analyses have been expounded in greater detail.

Deviation \# 1: The first example is from e e cummings' poem: "pity this busy monster, manunkind" (Williams and Honig, eds., 1962, p. 461). I am referring to the word monster,manunkind and the concept signified, and created, by it. Neither existed in English - which is why cummings, who needed them, had to create them - both the concept and the word for it.

The rules cummings deviated from here are the morphological rules of word formation and the rules on the use of blank space in writing. The rules cummings used are older and more general, the rules of succession (in time - in speech, and in space - in writing) and modification (of one word by another, placed beside it). The intention was, as already stated, the creation of a new concept, that of a "monster,manunkind", a being with characteristics which are the opposites of the best, idealized characteristics of a man, a human being.

The problem of translating this deviation into SC is the problem of a policy decision rather than a problem of actual translation because, in SC, there exists a word, a noun nečovek (together with the adjective nexovedan and the abstract noun - the quality of being neðovečan - necovestvo) defining the concept cummings was after. This can be well substantiated by consulting the corresponding entries in the existing English, SC and English-SC and SC-English dictionaries. In other words, the problem here was 
whether to use the existing SC word or invent a new one, the way cummings had done it in English. My suggestion would be to use the existing word. cummings' poem contains a lot of other deviations for the translator to deviate in the target language.

Deviation \# 2: The second example is also from cummings (Williams and Honig, eds., 1962, pp. 460-461). In his poem "anyone lived in a pretty how town" he used the pronouns anyone, noone, someone and everyone in a manner breaking a number of grammatical rules of standard English - but following rules of their own. In short, cummings used them as proper nouns, as names. As such, they can be used in all kinds of sentences (affirmative, interrogative, negative), they can have plurals and genders. With this in mind, it is relatively easy to understand the poem (to decipher what the poem is all about and find "the heroes" of the poem: a love story, but the lovers are not as famous as Samson and Delilah, Anthony and Cleopatra or Romeo and Juliet: the names of cummings' lovers are anyone and noone.

In SC, there exists a similar class of pronouns (biloko, niko, neko, svako) which should be used in translation, as proper nouns, as names. The fact that SC pronouns of this class possess visible (marked) genders and regular plurals does not make their use in the poem as nouns, as names, seem less deviant. A detailed analysis of the poem and the translation process itself are given in Jovanovic (1988).

Deviation \# 3: The third example is from Joyce's Ulysses (Joyce, 1960, pp. 659-704). It is the famous interior monologue of Molly Bloom, a single sentence beginning on page 659 and ending on page 704. This deviation is easy to explain (the whole of the text marked as a single sentence should be thought of as a single sentence) and understand (the text is what Joyce believed to be an interior monologue of Molly Bloom) and translate (at least from English into $\mathrm{SC}$, by doing the same).

Deviation \# 4: The fourth example is from Joyce's Finnegans Wake (Joyce, 1975, pp. 3-628). The only sentence of the first paragraph in it, for instance, starts with a lower case letter and ends with a full stop, like this:

riverrun, past Eve and Adam's, from swerve of shore to bend of bay, brings us by a commodius vicus of recirculation back to Howth Castle and Environs. 
The last sentence of the last paragraph of the book ends with no end punctuation mark, like this:

A way a lone a last a loved a long the

This deviation is more difficult to explain, understand and translate, although not very difficult. It is obvious - to me, at least - that the incomplete last sentence of the book should be connected with the incomplete first sentence of the book, like this:

A way a lone a last a loved a long the riverrun, past Eve and Adam's, from swerve of shore to bend of bay, brings us by a commodius vicus of recirculation back to Howth Castle and Environs.

Equally obviously - to everyone - Joyce did not combine them this way, but did it his way. Why? In my opinion, for the same reason Faulkner (1964, pp. 143-144) and cummings (Williams and Honig, 1962, pp. 460-461) had done it in their novel and poem respectively: to provide the readers with a particular background for interpreting their respective works. The beginning of a sentence is signalled by a capital letter and the end of a sentence is signalled by the presence of an end punctuation mark. No capital letter at the beginning of a sentence means "no beginning of the sentence". No end punctuation mark at the end of a sentence means "no end of the sentence". It's that simple.

In this example, the syntax of the two incomplete sentences and their meaning(s) "signal" the necessity for their merger. Once this is done, the sentence enfolds the whole of Finnegans Wake and turns it inside out, in a vicious circle. Also, bearing in mind one of the most popular definitions of the sentence (a complete thought), and the (literary) fact that Joyce's Ulysses depicts a day in the life of a literary personage, Leopold Bloom, one cannot but stop and wonder whether the whole of Finnegans Wake might not be just a thought in the mind of a literary personage: (Here Comes) Everybody, for instance! See Glasheen (1977).

Back to the deviation. This particular use of capital letters and punctuation, and almost the same deviations in the cited works of Faulkner and cummings, modify the meaning of the work by "forcing" the reader to interpret it, to look at it, from a particular, literary angle. What about translation? 
As already stated, the rules governing the use of punctuation and capital letters in English and SC are almost the same, which makes "translating" these particular deviations in Joyce, Faulkner and cummings, from English into $\mathrm{SC}$, a relatively easy task.

Deviation \# 5: Let us take a look at yet another example of the use (or lack of) punctuation and capitalization. In Faulkner's As I Lay Dying (1964, pp. 34-35), there is a chapter, an interior monologue of one of the characters of the novel:

Durn that road. And it fixing to rain, too. I can stand here and..., but durn them boys.

A-laying there, right up to my door, where every bad luck that comes...

Putting it where every bad luck... charging me taxes on top of it. Making me pay...

And Darl, too. Talking me out of him, durn them... Making me pay for it. She was well...

These are the beginnings of the five paragraphs stretching over two pages of the book. At first glance, there is nothing wrong with the text, but a good second glance, a detailed linguistic analysis (see, for instance, Jovanović, 1980/81), or an attempt at translating it, would reveal syntactic irregularities inside the sentences, as they are marked off here by punctuation and capitalization. An even more detailed analysis would show that there are really no syntactic irregularities, but deviations in punctuation and capitalization in addition to some deviations in paragraph organization. To understand the text, one should read it like this (the underscored text has been retrieved from context):

$\begin{array}{ll}\text { and } \begin{array}{l}\text { durn that road } \\ \text { durn it }\end{array} & \text { fixing to rain, too... } \\ \text { but } \begin{array}{l}\text { durn them boys } \\ \text { durn that road }\end{array} & \begin{array}{l}\text { a-laying there... } \\ \text { durn that road }\end{array} \\ \begin{array}{l}\text { keeping the folks restless... } \\ \text { putting it where every bad... }\end{array} \\ \text { and } \begin{array}{l}\text { durn Darl... } \\ \text { durn them... }\end{array} & \begin{array}{l}\text { talking me out of him } \\ \text { durn them }\end{array} \\ \end{array}$

What has Faulkner done here? Unlike Joyce who, in his Ulysses, has given his readers "the end product", the text he believed was the representation of the interior monologue of his character, 
Faulkner has produced only the stimulus which will "force" his readers to create, in their minds, their own interior monologues. In other words, the confusion in the minds of the readers which is the result of their attempts to process (grasp, understand) Faulkner's text is "the end result", the interior monologues of Faulkner's characters!

Now, what about translation? In order not to be a traitor, a translator should translate "the stimulus", and not his own reactions, deviations and not his or her own interpretation - the way most translators of this work of Faulkner's have done. See, for instance, Fokner (1976, pp. 25-27). As before, the first thing to do is to identify the deviation (the way it was done here) and its function (the way it was done here). And only then translate it - do the same thing in the target language, like this, for instance:

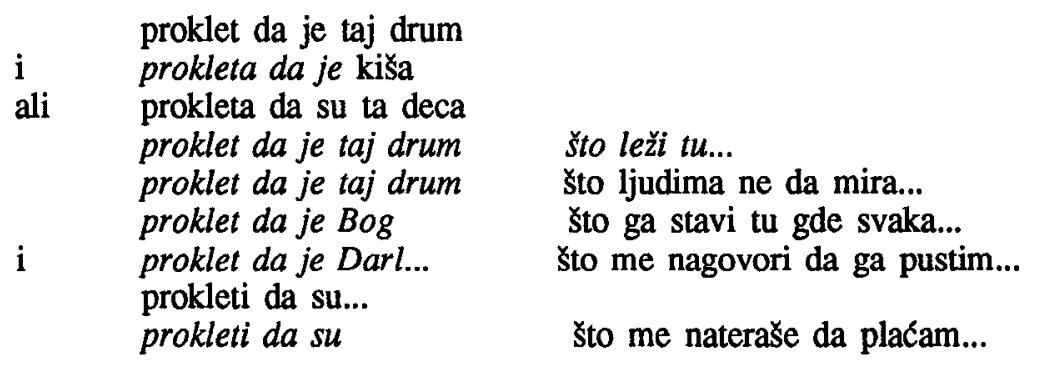

The parallelism and the syntactic regularity of these paragraph beginnings will disappear once these beginnings have been "returned" to their places and the original punctuation and capitalization of the text have been restored. On the surface, the SC text will appear as deviant as Faulkner's original, while remaining systematic and regular, underneath - which is exactly what, in my opinion, a translator should do.

Deviation \# 6: The last example I shall discuss here is also from Finnegans Wake (Joyce, 1975, pp. 215-216). Here is the text, the way it appears in the book:

Can't hear with the waters of. The chittering waters of. Flittering bats, fieldmice bawk talk. Ho! Are you not gone ahome? What Thom Malone? Can't hear with the bawk of bats, all thim liffeying waters of. Ho, talk save us! My foos won't moos. I feel as old as yonder elm. A tale told of Shaun or Shem? All Livia's daughtersons. Dark hawks hear us. Night! Night! My ho head halls. I feel as heavy as 
yonder stone. Tell me of John or Shaun? Who were Shem and Shaun the living sons or daughters of? Night now! Tell me, tell me, tell me, elm! Night night! Tellmetale of stem or stone. Beside the rivering waters of, hitherandthithering waters of. Night!

Like the rest of the book, this paragraph abounds in deviations on various levels which make it very difficult to understand. Difficult, however, does not mean impossible. (See, for instance, Jovanović, 1979a, 1979b, 1980 and Bugarski, 1983.) The first deviation, one which should be understood and "straightened out" before anything else is tried, is a literary deviation, so to speak, and not a linguistic one, although achieved by linguistic means. It is the question of who the addressor and the addressee are here. A close linguistic (psycholinguistic, in fact) analysis would reveal this prose text to be, really, a dialogue between two persons:

A: (1) Can't hear with the waters of. (2) The chittering waters of. (3) Flittering bats, fieldmice bawk talk.

B: (4) Ho! (5) Are you not gone ahome?

A: (6) What Thom Malone? (7) Can't hear with the bawk of bats, all thim leffeying waters of.

B: (8) Ho, talk save us! (9) My foos won't moos. (10) I feel as old as yonder elm.

A: (11) A tale told of Shaun or Shem? (12) All Livia's daughtersons.

B: (13) Dark hawks hear us. (14) Night!

A: (15) Night! (16) My ho head halls. (17) I feel as heavy as yonder stone.

B: (18) Tell me of John or Shaun? (19) Who were Shem and Shaun the living sons or daughters of?

A: (20) Night now!

B: (21) Tell me, tell me, tell me, elm!

A: (22) Night night!

B: (23) Tellmetale of stem or stone. (24) Beside the rivering waters of, hitherandthithering waters of.

A: (25) Night!

An even closer analysis would reveal that the sentences of the dialogue are rendered here as heard by the addressees and not as spoken by the addressors! In other words, the objective reader is given a chance to eavesdrop on the conversation of the two persons, or rather, to switch from the mind of one person to the mind of the other as the dialogue goes on! Also, the analysis of the context 
would reveal this to be a dialogue of two superstitious washerwomen (one of them, A, hard of hearing) washing clothes on the opposite banks of the river Liffey and gossiping about Ana Livia. The dialogue takes place under adverse conditions: it is already dark, the washerwomen are cold and tired and scared - they have scared themselves by talking about "fair folks" (elves) and "dark folks" (trolls, goblins). Of these, trolls are to be feared most, because they can turn a person into a tree (elm, stem) or a rock (stone). With the coming of the night, the sounds of the night grow stronger. The washerwomen cannot see and hear one another well and are in a hurry to finish the dialogue and go home.

With all this in mind, it becomes a bit easier to follow the dialogue and decipher and classify the deviations - thus making the paragraph "translation ready". According to my analysis, which took quite a long time to complete, this paragraph contains, and any translation of it should contain, the following (literary, organizational, linguistic, etc.) deviations:

1. Dialogue masquerading as a piece of prose text.

2. Part of the text rendered as heard, not as spoken.

3. Reader following the interior monologues of two persons (Livia is Liffey; Livia has two sons, Shaun and Shem; Liffey has two banks, with stone and elm: two washerwomen on two banks of the river; the whole book, as signalled by the first/last sentence, is a thought in the mind of...).

4. Sentences 1,2 and 3 are fragments of a single, but not coordinated sentence.

5. One participant in the dialogue, $\mathrm{A}$, is hard of hearing. As a result, we have "echo" dialogues where A substitutes what "she has heard" for what B has actually said:

-Are you not gone ahome?/What Thom Malone?

-I feel as old as yonder elm./A tale told of Shaun or Shem. -I feel as heavy as yonder stone./Tell me of John or Shaun? Also, and for the same reason, A "hears" Ho, talk save us! instead of $\mathrm{Ho}$, Lord save us! uttered by $\mathrm{B}$.

6. Freudian "slips of the tongue", examples of utterances combining intentional and unintentional communication: bawk talk, bawk of bats, my foos won't moos, my ho head halls and dark hawks 
hear us (instead of balk talk, talk of bats, my foot won't move, my whole head falls and dark folks hear us). ${ }^{2}$

7. Literal graphic representation of spoken utterances (in speech, there are no "blank spaces" (pauses) between individual words, only between sense groups:

-daughtersons (daughters or sons)

-hitherandthithering (hither and thithering)

-tellmetale (tell me a tale)

-night (good night)

8. Selectional hearing (hearing words which had not been uttered, by combining parts of the uttered words). The word elm in sentence 21 , which is a combination of the last two sounds of the word tell and the first sound of the word me. (see, also, Jovanović, 1977).

9. The stylistic device of alliteration:

-flittering... fieldmice

-thim liffeying

-chittering...flittering...rivering...hitherandthithering

10. Identical, or similar, sounds (vowels) in the names of Livia's sons -Shaun and Shem - and the things they (are) turn(ed) into - stone and elm.

Here is what a translation into SC might look like, with all the deviations built in (except for the names of things Shaun and Shem turn into).

A: Ne そujem od voda ovih. Žuboravih voda ovih. Od కišmiša što kriß̌e, miß̌eva što ciß̌e.

B: Hej! Još nisi otišla kući?

A: Koga će Tom tući? Ne cujem ništa od šišmiša što ciše, od grdnih voda lifijskih.

2. "The disturbance in speaking which is manifested in a slip of the tongue can in the first place be caused by the influence of another component of the same speech - by an anticipatory sound, that is, or by a perseveration - or by another formulation of the ideas contained within the sentence or context that is one's intention to utter." Freud (1972, p. 56). I should add that slips of the tongue usually occur when a person is tired, excited, scared, etc., just like our two washerwomen here. For a detailed analysis of Joyce's use of these Freudian slips of the tongue, see Jovanovic (1979a, 1979b and 1980). 
B: Gospode oglasi nas! Koča mi se unogila. Kao da sam kao klada.

A: Šta kažeš o Šonu il' Šemu sada? O onim Livijinim sinovićerima.

B: Mračne mile mogu da nas čuju. Kunoć!

A: Kunoć! Plava mi gada. Kao da sam kao stena.

B: Džon il' Šon su im imena? Ĉiji beše zapravo Šon il' گ̌m sinilćer?

A: Laku noć!

B: Kaži mi sada, kaži mi sada, kaži mi klada!

A: Kunoć kunoć.

B: Kažimikaži o steni o kladi. Pored krivudavih voda ovih, pored ovudaonudavih voda ovih.

A: Kunoć!

\section{Conclusion}

What can be concluded from all this? At least three things. First, that deviations from the norm (or breaking the rules of language, or experiments with language or poetic licence, or...) are here to stay which means they should be accounted for in every discussion on language and language communication, and in translation. Second, that at least one of the assumptions I started from in this paper (in good writers, deviations from the norm are, themselves, systematic, that is, they follow certain rules of their own, and systemic, that is, originate in the language system they deviate from) is true. In its turn, this means that these deviations, no matter how arcane they might appear at first, lend themselves to analysis (like "the rest of language") and, ultimately, to translation (like "the rest of language"). And third, translation theory, as defined in this paper, can help translators (those capable of rather detailed linguistic etc. analyses) carry out their task with better success.

As for actual translation of the deviations presented here into languages other than SC, I can propose neither universal guidelines nor specific solutions - apart from sample translations into SC given here. All I or anyone else can do is identify the problem(s). The solutions would depend on the target language, target literature, target culture. The universal cognitive structure of the human mind, which makes for linguistic universals and, ultimately, makes all translation possible, if properly applied to the problem, will do the rest. 


\section{References}

BUGARSKI, Ranko (1983). Lingvistika o čoveku. Beograd, Prosveta, 266 pages.

FAULKNER, William (1964). As I Lay Dying. New York, Random House, 250 pages.

FOKNER, Viljem (1976). Dok Ležah na samrti. Beograd, Rad, 168 pages.

FREUD, Sigmund (1972). The Psychopathology of Everyday Life. London, Ernest Benn Limited, 310 pages.

GLASHEEN, Adaline (1977). Third Census of Finnegans Wake. Berkeley, University of California Press, 314 pages.

JAMES, Joyce (1973). Ulysses. Harmondsworth, Penguin Books, 704 pages.

(1975). Finnegans Wake. London, Faber and Faber, 628 pages.

JOVANOVIĆ, Mladen (1977). "Poredenje uticaja koji na neposredno pamćenje imaju ponavljanje reči i uključivanje asocijativnog para". Zbornik radova Filozofskog fakulteta u Nišu, knj. IV, pp. 241-254. Niš, Filozofski fakultet.

(1979a). "Ana Livija po cetvrti put na srpskohrvatskom", (I), Mostovi, 39, pp. 226-232. Beograd, Udruženje književnih prevodilaca Srbije.

(1979b). "Ana Livija po ćetvrti put na srpskohrvatskom", (II), Mostovi, 40, pp. 294-303. Beograd: Udruženje književnih prevodilaca Srbije.

(1980). "Ana Livija po cetvrti put na srpskohrvatskom", (III), Mostovi, 41, pp. 52-61. Beograd, Udruženje kniževnih prevodilaca Srbije. 
(1980/81). "Prevodenje i stil: slućaj Foknerovog romana As I Lay Dying". Godišnjak SDPLJ, 4-5, pp. 253256. Zagreb, SDPLJ.

(1988). "The Relationship between Theory and Practice: An Example". Translation, our Future: XIth World Congress of FIT, ed. by Paul Nekeman, pp. 85-92. Maastricht, Euroterm Maastricht.

WILLIAMS, Oscar and Edward Honig, eds. (1962). The Mentor Book of Major American Poets. New York and Scarborough, New American Library, 535 pages. 